\title{
部分的一時的機能低下を許容する重要拠点のファシリテイプログラミング に関する一考察 \\ A CONSIDERATION ON FACILITIES PROGRAMMING FOR EMERGENCY MEASURE BASES ACCEPTING PARTIAL AND TEMPORARY FUNCTION DROP
}

柳父行二*

Koji YANABU

\begin{abstract}
This paper introduces facilities programming process based on business continuity plan. To sustain facility function of emergency measure base is one of crucial business goals. To cut down investment as well as reduce function drop and shorten recovery time are required to specify facilities. Organizing impact network system with several elements such as the number of bases, distance between bases, probable emergency and measures, simultaneous damage probability at plural bases, function recovery scenario and time, and management resource investment policy, clarifies the relationship between business goals and facilitis' specification. Those elements are variable, then organizing structure based on peculiar condition is recommended instead of copying precedent.
\end{abstract}

Keywords : Facility Management, Briefing, Office Planning, Business Continuity Plan, Emergency Management ファシリティマネジメント, 設計要求条件整理, オフィス計画, 事業継続計画, 有事対策

1. はじめに

\section{$1-1 \quad$ 事業目的達成とオフィスファシリティ整備}

事業活動は、ヒト・モノ・カネを代表とする経営資源を投入管理 し、ある目的を達成することと捉えることができる。建築・設備・ 家具・道具・文具などのオフィスファシリティ（以下ファシリティ） はモノに属し、事業活動の主体であるとトの活動を支援することに より、事業目的達成に貢献する。ファシリティの種類と量が増え投 資額が増大すると共に使い方が複雑化すると、事業者固有の事情に 合うようファシリティの過不足を削減することが、投資効果の高い 事業活動を行うための重要な課題になる。

ファシリティの過不足削減は、事業活動の主体であるヒトが十二 分に力を発揮できるよう、安全と健康を確保した上で業務手順や業 務行為を支援するという階層構造をなすと考えられる。業務手順や 業務行為は、競合商品や顧客の購買意欲が変化し、あるいは社内の 商品製造・調達能力が変化すると、競争力の確保や業務効率向上の ために組み直さねばならず、ファシリティもそれに合わせて整備し
なおすことが求められる。

\section{$1-2$ 有事対応とファシリティ整備}

業務手順や業務行為の急激な変化に有事対応がある。事業活動の 重大な有事には、顧客が商品や効用を購入しなくなる場合と、商品 や効用が提供できなくなる場合がある（図 1)。前者の事例にはりコ 一ル隠しによる顧客離れ ${ }^{1)}$ があり、偽装に端を発し事業清算に至つ た企業もある2)。後者には地震での工場損傷による製品出荷停止が あり、事業規模を縮小せざるを得なくなつた事例もある3)。事業を 円滑に遂行するには、顧客離れにつながる有事の影響を小さくする ことが重要で、事業継続計面注1) が有効とされる4)。

有事に機能を確保しなければならない部門は事業継続計画で重要 拠点と呼ばれ ${ }^{4)}$ 、有事対応の拠点と、有事にもサービスを継続提供 しなければならない拠点がある。前者の事例には、製品欠陥が判明 した時に、原因究明、対策立案、顧客への連絡などの業務を、短期 集中で行う場所が上げられる。後者の事例には、事業エリアの有事 
の時こそ業務機能を維持しなければならない都市ガスのコールセン ターが上げられる。本論文では後者について考察する。

\section{$1-3$ 重要拠点の確保に関わる課題}

業務機能を確保するには、有事の影響を小さくすることが必要で、 有事発生を抑制し、人命の安全と健康を確保し、拡大を抑制し（防 衛)、業務機能低下を抑制し (延命)、早期復旧する手立てを整理し、 設計要求条件にまとめることが求められる（図 2)。

重要拠点の確保に関わる先行研究には、地震、洪水、火災などの 有事で発生する現象を把握解明し、影響を小さくする方策を考案し、 その効果を検証するものがある。火災や地震に関する研究は数多く、 材料や構造を選べば影響を小さくできることが示されている。しか し、業務機能を確保するには、通信やエネルギーなどの重要拠点外 との入出力路も含めなけれれ゙ならないなど、全ての有事を網羅し対 策を施すには要素が多く、合理的な投資上限の設定という新たな経 営課題が発生する。機能を維持し続けなければならなり重要拠点の 有事対策は、課題を単純化させることが重要で、想定しなければな らない有事の数を減少させることが望まれる。想定有事の数を減少 させるには、同時被災を回避しながら拠点を多重化させる手法があ る。どこかの拠点が確保されるなら、重要拠点確保のための課題は、 機能低下の抑制と復旧時間の短縮に変換される。

有事における複数建物の問題を取り扱った先行研究には、地震動 の相関有無による地震リスクを評洒し分散配置の効果を示した諏訪 らの研究(6)や、イベントツリーを用いて地震被害確率を評価し被害 額低減に効果のある事を示した水谷らの研究7)がある。また、地盤 条件や建物構造などの地域特性を考慮し、複数の医療施設の災害時 需要と供給の不均衡をシミュレーションで示した平山らの研究 ${ }^{8)}$ も ある。しかし、複数拠点を連動させ、機能低下抑制と復旧時間短縮 と投資抑制を課題としたファシリティ整備の先行研究は見られない。

\section{1-4 研究目的と方法}

本研究の目的は、部分的一時的機能低下を許容する重要拠点の設 計要求条件整理（ファシリティプログラミング）て解決しなければ ならない特有の課題と解決法を事例に基づき抽出し、経営課題とフ アシリティ設計条件を関倸付けることとする。

事例とは、それまで5籄所あった都市ガスのコールセンター注 22 を 2 籄所に集約した際の設計要求条件整理である。5拠点にはそれ ぞれ担当区域があり、平時の相互補完機能はなく、経験知に応じた 有事対策をそれぞれて講じるという考え方であった。経験知とは、 30 年を超える歷史を持ち、有事で問題が発生するたびに改善を加え てきた別種の重要拠点の考え方である。どこかの拠点が機能停止し ても全体を巻き込むことは無いと考えられ、他の拠点から応援に駆 けつければ拠点機能は回復すると想定していた。2拠点になると片 方が機能停止した場合の影響が大きいので、経験知より増強が必要 な部分と、機能連動という優位性を活かし削減できる部分があった。

研究方法は、まず有事対策要素を 5 拠点時代の考え方から抽出し た。要素抽出は、事例プロジェクトに参加の建築・機械・電気・計 装担当による設計会議での議論ならびに発注仕様解説に加え、筆者 による追加の質問に基づいている。各担当者の説明で不十分な場合 には、その担当者を通じて先人の考えを確認した。また、論文にま

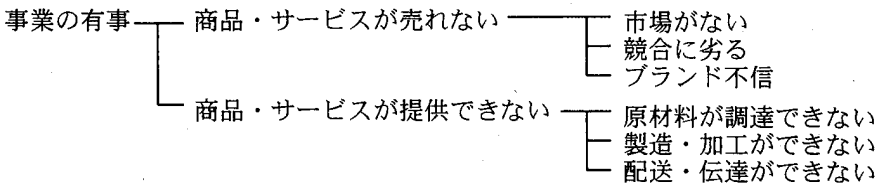

図 1 事業上の重要有事

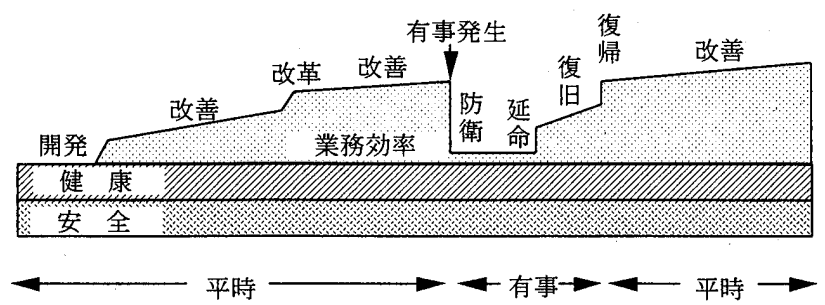

図2 平時と有事の段階とファシリティ整備の期待効果

とめる時期に疑問が出た場合には、関係者に追加の質問を行った。 直接質問したのは 7 名程度であるが、担当者を通じて情報收集した 人数は倍程度になると考えられる。設問は有事対策のための特殊仕 様とその期待効果とした。調査期間は事例プロジェクトのプログラ ミング時期全てと、論文として整理するための時期で、数年に及ぶ。

有事対応要素が把握できた後に、拠点を連動させた場合に考慮す べき区分と段階に整理した。さらに、業務継続と投資抑制とする経 営課題を分析し、連鎖を整理しながら、機能連動による增強必要性 と削減可能性を検討した。そして、増強と削減の案が出来てから、 経営課題とファシリティ設計条件とを関係付ける連鎖を構成しなお した。

\section{2. 重要拠点の業務継结とファシリティの確保}

重要拠点での業務を円滑に遂行するには、能力を有するヒトと、 ヒトの能力を発揮させる道具と、ヒトの居場所と道具の設置場所と しての空間を確保する必要がある。ヒトの確保は安全と健康と能力 と手順と士気に分解することができる。安全には建築構造や機器や 家具の固定方法や防消火設備などが関わり、健康には照明・空調・ 給排水などが関わる。士気に大きな影響を及ぼすのは業務そのもの で、ファシリティは業務の進め易さを通じ、間接的に関わると考え られる。道具の確保は、道具そのもの機能々機能発揮のための業務 基盤に分解することができる。業務基盤は電源・通信・空調に関わ る。空間の確保は、広さと業務基盤に分解することができる。広さ は平時業務での利用場所と有事での利用想定場所が確保できればよ く、建築構造や機器や家具の固定方法などが関わると考えられる。

(図 3)。よって、ファシリティの機能確保は業務秤続の必要条件と なる。

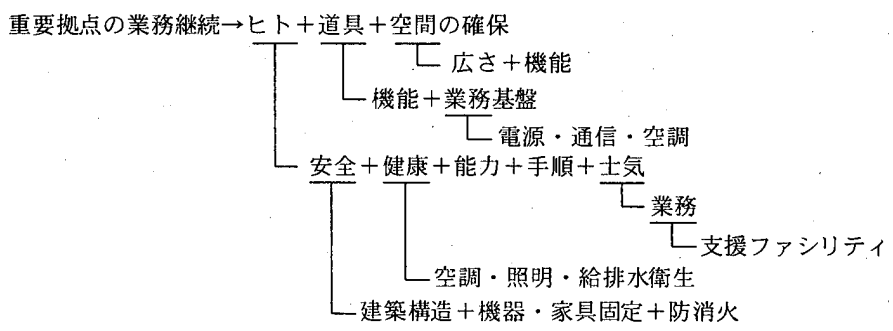

図 3 重要拠点の業務梿続と必要なファシリティの連鎖 
3. 機能低下 の抑制

機能低下要因 と対策は、30 年 以上運用乙有事 で問題が発生す るたびに改缮を 加えてきた別種 の重要拠点での 設備設置理由学、 建築・機械・電 気・計装を担当 してきた諸先輩 に問い、原因種 別之有事段階に

分け、整理した。なるべく多くの有事を視野に入れるようにしたが、 拠点多重化亡同時被災の回避策に基づき考慮す心゙き有事を削減する ので、機能低下要因と対策は主要事象を外さない範囲で典型例を整 理するにとどめた。

\section{3-1 典型的な機能低下要因}

重要拠点の機能低下要团は、外因性と内因性に分けることが出来 る。外因性に流、地震・雷・台風・洪水等の自然災害系のもの之、 延焼やテ口等の人為災害系のもの之、建物外部の通信ラインやエネ ルギーライン障害等の異常発生系のものがある。内因性に注、菜務 手順の誤りによる顧客対庥不全や機器の誤操作や失火やテロ等の人 為災害系之、サーバ一異常、通信機能異常、電源異常、機器の劣化 や過熱による故障や火災発生などのファシリティ異常系がある。ま たコールセンターでは受付対応者の勤務体制による人手不足も機能 低下要因となりうる（表 1)。

\section{3-2 典型的な有事対策}

ファシリティによる対策を有事の段階別に概観すると、自然災害 の発生そのものを防止することは困難であるが、地震には耐震・制 震・免震などの建築構造上の対処法で、雷には避雷針やアレス夕、 台風には建築構造、洪水には床高さや止水板で、重要拠点の機能低 下を抑制することが出来る。延焼やテロによる被害などの外因性人 為的有事に対しても、建築材料で拉大を抑制することが出来る。重 要拠点外とモノのやり取りを行う通信うインやエネルギーラインの 機能不全には、チャンネルの二重化や代替エネルギーの確保なごで 機能低下を抑制することが出来る。誤操作などの内部の人間が原因 となる有事は、ヒューマンエラ一抑制㙨能付加で、有事の発生その ものを防止することが出来る。テロや锴盗などの内部の人間が意図 的に起こす有事には、監視装置や何をしているかが周りから見える 環境を作ることで発生を抑制すると共に警報装置で早期発見し拡大 を防止することが出来る。ファシリティの劣化故障には、定期検查 で発生を、警報装置で应大を、二重化や代替品の準满て機能低下を 抑制することが出来る。機器の過熱故障は、空調や警報で発生を抑 制することが出来、警報や消火設備で拡大を抑制することが出来る。 人手不足は、照明や空調を正しく運用して要員の健康を維持すれば
発生

その

もの

を抑

\begin{tabular}{|c|c|c|c|c|c|}
\hline & & & & & 供洘 \\
\hline 拠点数 & 5 & 4 & 3 & 2 & 各拠点は同等、計 $100 \%$ \\
\hline 機能低下レベル & $80 \%$ & $75 \%$ & $66 \%$ & $50 \%$ & 1 拠点機能衰失時 \\
\hline
\end{tabular}

制することが出来、休憩中の要員に信号を送ることにより席に帰る よう促すことが出来れば早期回復を促進することが出来ると期待さ 机る(表1)。

上述のように、機能低下要因の数が多く対策も多岐に亘る。全て の要因之対策を網羅するこ己は困難で、表 1 は典型的な事象の列記 に留まる。また、考えられる対策を全て講じると投資額が膨大とな る。有事は既往最大で考えるという技術的な限界もあるので、設備 の増強だけで万全な有事対策は立て難い。単独拠点で事業継続の信 頼性を確保し、かつ投資を抑制するのは困難であると考乥られる。

\section{3-3 拠点数と機能低下レベル}

拠点を複数にすると、どこかで有事か溌生しても同時被然さえ回 避すれば、拠点機能を部分的に確保することができる。たとえば拠 点数が二で合計能力が $100 \%$ か機能が同等なら、同時被災が無い 限り、一方が有事で機能停止しても、機能低下レベルは $50 \%$ となる。 機能低下レベル 50\%が許容できない場合には、拠点数を增加させれ ば、1箇所の機能を失った場合の影響を小さくすることができる。 拠点能力が計 $100 \%$ か同等の場合の、拠点数と 1 拠点が機能を垫 失した時の機能低下レベルの関係を表 2 に示す。拠点数を增加させ ると機能低下レベルを抑制することが出来る。

同時被災回避は 5 章で考察する。

投資額は、規模のメリットの無いものとあるもとの組みあわせと なる。コールセンターのように受け付け能力が受け付け要員数にほ ぼ正比例する場合に活、執務室の広さや個々の受付係が使用する道 具の費用は拠点数多寡の影響が小さい。一方受電設備や電話交換機 などは規模のメリットがあるので、多くの拠点に分散配置するとフ アシリティへの総投資額が增大する。

機能低下レベルを抑制するために拠点数を増加させると、規模の メリットのある機器費用が増大するというトレードオフを生じる。

事例での両拠点の能力は平時必要分の $70 \%$ と $30 \%$ であったので、 許容される機能低下レベルは $30 \%$ とった。 


\section{4. 復旧時間の短縮}

重要拠点機能が何割も低下した場合に機能を復旧するには、 有事発生拠点を放㲤し健全な拠点を増強する方法と、被災拠点 に残留し補強する方法がある。

健全な拠点を増強するには、技能を有する要員と人数分の業 務基盤を追加で確保しなければならない。常に増強分の要員と 人数分の業務基盤を準備すると、初期投資と運用コストが増大 する。部分的一時的機能低下を許容するという経営上の施策を生か し投資削減するには、被災挑点から要員が移動し、手持ち可能な機 器を持ち込む万法が考えられる。ただし、健全な拠点だけで業務を 継続すると次に有事が発生した場合に機能低下レベルの下支えがで きない。健全な拠点での増強は仮復旧で、次の有事に対する能力も 含めた本復旧とは区別し取り扱う必要がある。そこで、健全な拋点 の増強に要する時間を仮復旧時間、被災拠点の機能を復旧する時間 を本復旧時間亡区別し考察する。

被災拠点を補強する場合は、業務基盤整備時間が本復旧時間とな る。被災地点に残留するのは、健全な拠点への移動時間より短い時 間内に機能回復が期待できる場合で、どちらが早いか判定困難な場 合には一部を待機させ残りを移動させる方法などがある。

\section{4-1 仮復旧時間の短縮}

被災拠点から要員が移動し、手持ち可能な機器を持ち込む場合注 空間と手持ち困難なサーバーや電源や通信設備など道具系空間系つ アシリティは事前準備をしておかなければならない。仮復旧時間を 短縮するには、拠点間距離を短縮するという選択肢がある。ただし、 同時被災を検討しなけれればならない有事が増え、被災可能性も高く なり、有事対策のための費用が増大するという弱点がある。

仮復旧時間を短縮する他の手法に、健全な拠点で他業務に利用し ている業務基盤を転用し、他業務に従事している人材で業務を代行 する方法がある。業務基盤が転用可能であることと、人材が重要業 務を遂行できることが条件となる。（図4）

事例の場合、業務拠点か隣接していて、基盤機能の転用とヒトの 代行が可能なので、仮復旧時間は 0.5 時間から 3 時間程度と見積ら れた。

コールセンターの場合には、代行能力を確保するために、夜間休 日の受付を多くの従業員に交代で経験させることが有効と考えられ る。また、能力のある人材と通信手段が確保できれば、電源や照明 が無くても、空からの入射光の下に㧍客さまの要望を把握し必要な 手配を行い紙に記録を残すことで、機能低下レベルが抑制できると 期待される。

\section{4-2 本復旧時間の短縮}

被災拠点以外で機能を増強し仮復旧した後は、次の有事に備え、 元の拠点数之有事対策能力に戻す必要がある。本復旧に要する時間 は、ディスクの破損のように機能を失ってしまった場合には入れ替 えに要する時間、エネルギー供給障害のように機能発揮に必要な外 部の機能が失われた場合には外部機能の回復時間となる。ただし、 有事の連鎖反応で突然機能を停止させた場合に、引き金となった有 事が解消されても元の状態に復帰できない業務基盤には、突発的な 停止を回避し計画停止にするための時間を確保する手段が必要であ

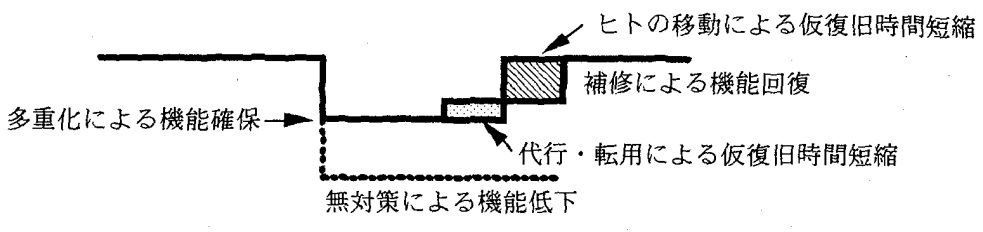

図4，機能低下抑制之仮復旧時間の短縮

る。想定有事はディスク書き込み時の停電で、サ一バーなどの手動 停止を判断しバックアップをとるなどの時間も含めた容量の無停電 電源が必要である。

\section{5. 同時被災回避の検討}

複数拠点での同時機能低下要因は外因で、拠点間の距離か漓隹れる に従し想定しなければならない有事の数が減少すると期待される。 ただし、距離か離れると、被災拠点から健全な拠点への移動時間が 長くなり、ヒトの移動による仮復旧時間が延びるという弱点がある。 そこで、約 $50 \mathrm{~km}$ 離れた事業拠点事例に基づき、どのような検討を すればよいかを考察する。二拠点は大阪市内Dビルと京都市内Pビ ルで、いずれも既築ビルある。

\section{5-1 同時被災回避検討}

拠点が異なれば、テロ以外の内因による同時被災は除外してもよ いと思われる。テロ対策は本論から除外する。検討すべき要因は外 因で、50km離れていれれば、雷や洪水や延焼や通信障害やエネルギ 一障害による同時被災は無い上考えてよいであろう。検討すべき機 能低下要因は地震だけに絞られよう。

重要拠点設置階の機器機能に問題を生じるか否かを判定したいの で、地表の震動だけでなく、設固階への増幅も考えなければならな い。地表面震動は、想定されるリニアメントの位置と長さを元に、 Joyner-Boore 式ならびに拠点近くの地盤条件を用いて而地区での 震動を予測する後藤らの手法 ${ }^{14}$ を用いて求めた。次に想定階への 増幅を加え、設置された重要機器機能に問題を生じるか否かを非構 造部材の耐震設計法や 1995 年兵庫県南部地震での実績に基づき検 討した。機器の耐震性は設計計算の考え方に兵庫県南部地震の実績 を加味し判定した。両拠点での地表地震動と、主要ファシリティの 而震性評価を図 5 に示す。

図 5 の縦軸蛙Dビル地表での推定加速度、横軸はPビル地表での 推定加速度で、近在に想定されるリニアメントによる両地区での推 定震動を表示している。たとえば上町仏念寺山が震源の場合には、 Dビルの地表では $700 \mathrm{gal}$ 程度、Pビルの地表では $100 \mathrm{gal}$ 余りの震 動と推定される。ただし、計算はリニアメント全長が震源になるこ とを前提としているが、現実にはりニアメントの一部が地震を引き 起こす場合も多い。上町仏念寺山が破壊すれば必ず図示の地震動に なるという意味ではなく、最大規模での想定を示している。

縦軸左と横軸下に示す構造、消火、空調、電源、燃料の棒グラフ は、ファシリティ改造案の建物全体あるいは重要拠点設置階での耐 震性評価を示す。健全、機能低下、機能損失の3 種類の判定とした が、判定精度はそれれど高くないと考えられるので、影響が出ると 考えられる地表面加速度に幅を持たせた。 


\section{5-2 同時被災検討に基づく D ビル設計要求条件の整理}

構造 : Dビルには保安用無線塔 が上乗せされ、強風時のアンテナ 振れ角制限を満たしていたため、 1995 年兵庫県南部地震級でも継 続使用に耐えると考えられた。構 造補強は不要と考えられる。ただ しサーバーは震動に強くないので 免震装置設置を条件とした。

消火設備 : 誤動作による情報機 器障害が考えられるため、スプリ ンクラーから不活性ガス消火への 変更が望ましい。

電源 : 瞬停を起こすと復帰に手 間の掛かるサーバーがあるので、 無停電電源が必要である。無停電 電源の負荷は瞬停が発生すると復 帰困難な機器に限定し、情報機器 の通常停止操作に必要な時間の容 量でよい。また、商用電源が停止 すると、事業区域の大部分は問題 ないのに重要拠点だけが機能不全 に陷る可能性があるため、保安用 発電装置を設け、燃料を確保する必要がある。燃料は 1995 年阪神大 震災でも供給を継続したという害績のある中 B ガスを、隣接するガ スホルダーから受け入れることでよい。負荷は照明・空調・給排水・ 防消火設備で非常時にも必要な機器のみに限定する。

空調 : 情報機器の発熱防止が主目的で、サーバー用空調冷凍機の み二重化し、保安用電源系に載せる必要がある。

給排水 : 発電機冷却用水之空調用水之生活用水の確保が目的で、 24 時間使用分の容量を持つ受水槽を設け、揚水ポンプ（複数）を保 安用電源系に載せる必要がある。

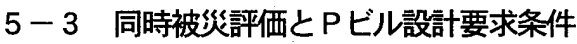

最も脆弱と考えられるのはサーバーで、Dビルでの地表震動が 400gal を越えると何らかの問題が生じる可能性があると推定され
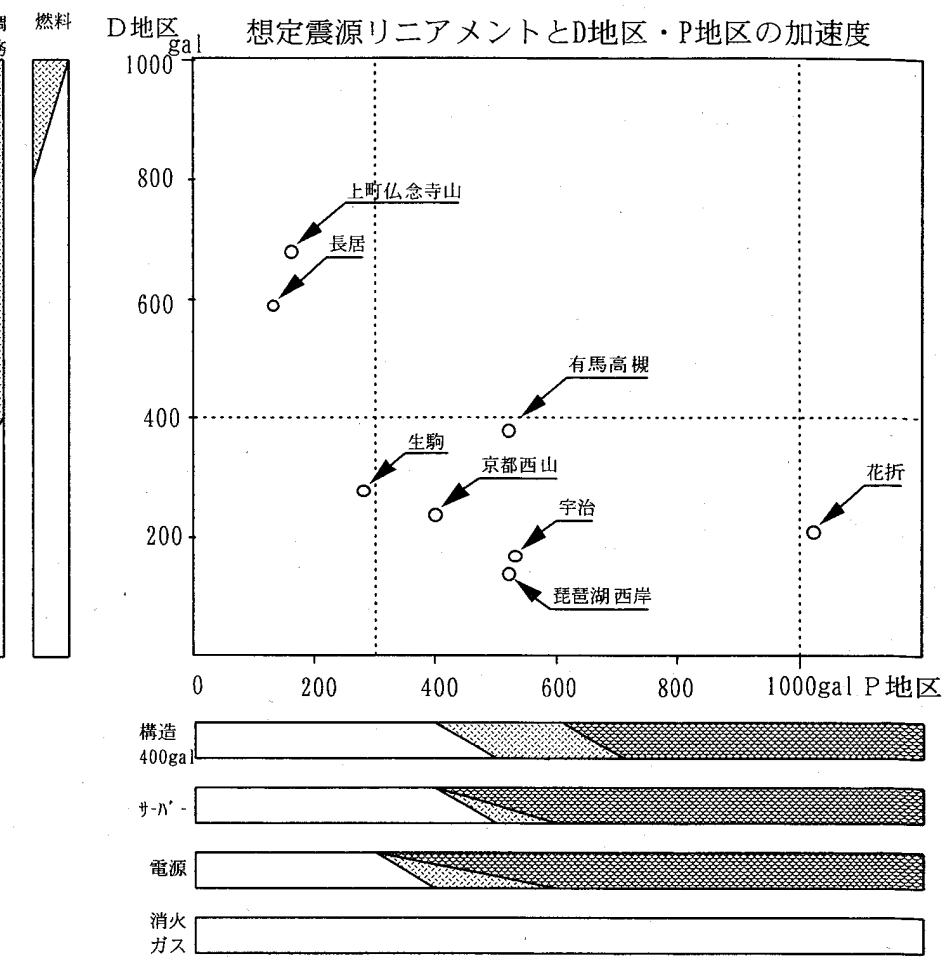

空調

図5 同時被災の検討例

る。Dビルでの地表震動が 400gal を越える可能性があるのは上町仏 念寺山と長居で、ほぼ400gal になるのが有馬高槻であった。

これら 3 つの想定地震のうち、上町仏念寺山と長居でのPビルの 地表震動は 200gal 未満で、床で 200gal 程度を限界值にしている情 報機器以外は耐震補強なしでも同時被災は無いと判定される。Pビ 儿設置の情報機器は 1995 年兵庫県南部地震で地表 $300 \mathrm{ga} 1$ の震動が 観測されたが問題を生じなかったので、同時被災は無いと判定され る。有馬高規でのPビルでの地表震動は 500gal を少し越えると推定 され、通常の耐震設計によるPビルでは、設備のどこかで何らかの 障害が発生する可能性がある。同時被災の評価はグレーとの判定も ありうる。地震動の推定にリニアメント全長が一度に破壊するとい う前提を設けていることや、有馬高柣の生起確率が低(注3)ことを 勘案すれば、サーバーの免震床や保安用発電機の設置を取りやめる

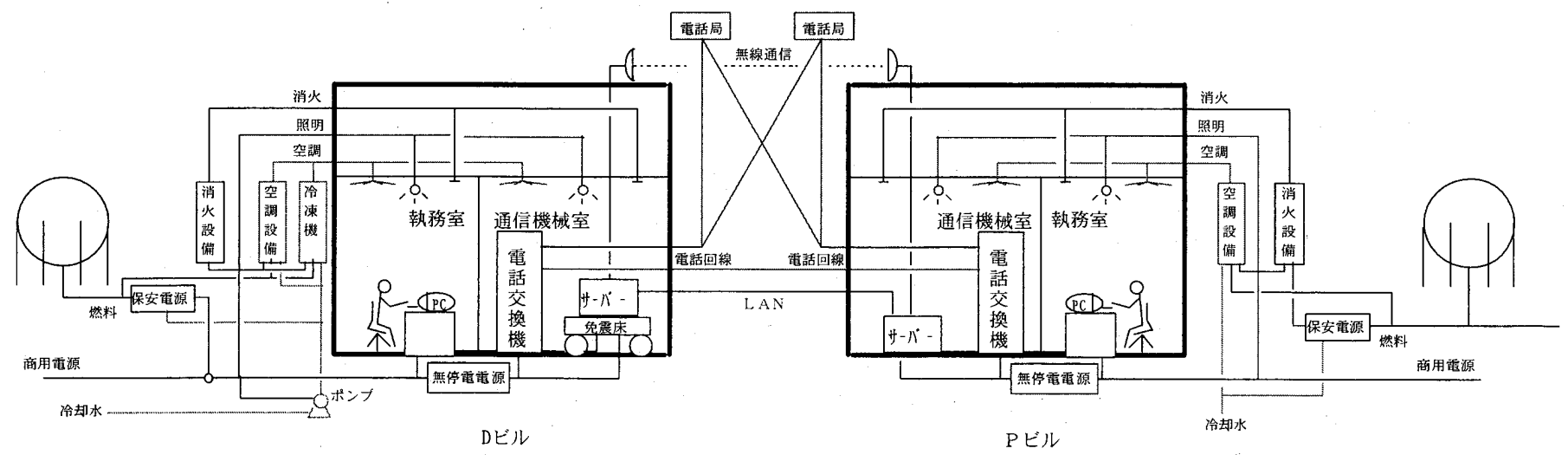

図 6 コールセンターの有事対策設備構成例（概要） 
ことも可能である。投資削減の点では評価が微 妙な地震である。

以上の検討に基づき、Pビルはサーバーの免 震床と保安用電力を設置しない案を提示した。 建築設備の構成例を図 6 に示す。

\section{6. まとめ}

部分的一時的機能低下を許容する重要拠点で のファシリティ機能の設計要求条件を整理する プロセスを、都市ガスのコールセンターでの経 験を参照しながら考察してきた。

固有の課題には、機能低下抑制と復旧時間の 短縮があつた。課題と解決策を分析すると、機 能低下抑制は拠点多重化と同時被災の回避に、

復旧時間の短縮は業務基盤の転用之業務の代行 に変換できる。担当者移動で復旧時間を短縮しようとす ると、機能低下抑制のための拠点間距離の確保とトレー ドオフを生じる。

経営課題とファシリティ仕様の関係は、小分けにした 課題の解決策を整理し、トレードオフを明確にしながら 連鎖を組み上げていくことで、投資目的が明確な設計要 求条件を提示することができる。本論分で構築できた連 鎖構造を図 7 に; 有事段階とファシリティによる対策と の関係を表 3 に示す。

本論文では有事想定とその対策や同時被災の可能性な どを取り扱っているが、まだまだ初歩的な段階である。 過不足を削減するにはさらにデーターを蓄積し手法を開発すること が望まれる。また、有事は既往最大で考えるという技術的な限界が あるため、一旦作った有事対応シナリオの結果より、解を導くプロ セスをノウハウとすべきと考えられる。

\section{謝辞}

本研究でとりあげたファシリティプログラミングのノウハウは 3. 機能低下の抑制で示したように、諸先輩の業績の積み上げに基 づいている。一人一人のお名前を挙げることはできないが、後輩に ノウハウを残していただいたことに対しお礼を申し上げたい。また、 本研究の基盤となった設計要求条件整理事例は前坂昌道氏、岡克己 氏、網屋千代吉氏のご協力のもとに実施したものである。お名前を 挙げ、謝意を表します。

注

1）事業継続計画（BCP）は「災害時に特定された重要業務が中断しないこと。また万一 重要業務が中断された場合に目標復旧時間内に重要な機能を再開させ、業務中断に 伴う取引䳡客の競合他社への流出、マーケットシェアの低下、企業評価の低下など から企業を守るための経営戦略。バックアップシステムの整備、バックアップオフ ィスの確保、安否確認の迅速化、要員の確保、生産設備の代替などの対策を実施す る。」）とされる。商品の製造・調達や販売に関わる事業中断リスクを想定し、事業 への影響を予測し、許容可能な事業活動中断期間を分析し、抑制したい影響範囲を 特定し、手当てを考え、訓楝し、有事に備えることが計画の範囲に含まれる。

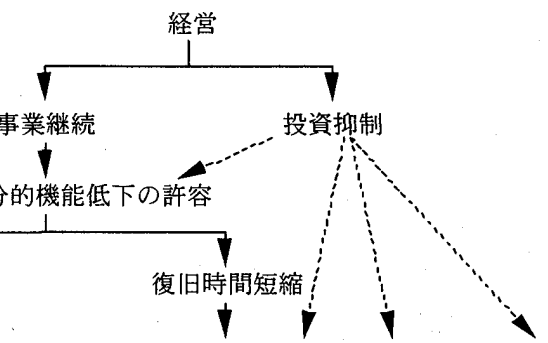

重化十同時被災回避担当者の移動十七ノの転用十七トの代行

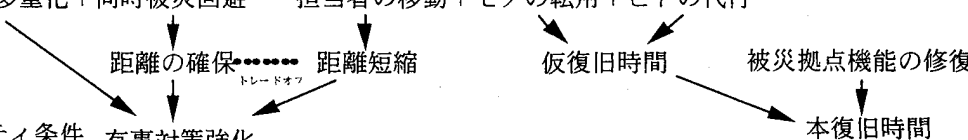

图 7 本論分で考察した経営課題からファシリティ設計条件への連鎖

表 3 有事段階とファシリティによる対策

\begin{tabular}{|c|c|c|c|}
\hline & 有事発生抑制：有事㧨大抑制 & 同時被災の抑制 & 機能低下抑制：早期復旧：投資抑制 \\
\hline 拪点多重化 & & & O. \\
\hline 構造 & o. & 0. & . \\
\hline 兔震床. & o. & . & ㅇ. \\
\hline ガス消炎 & ㅇ. & & ㅇ. \\
\hline 無停電電源 & & & O. \\
\hline 発電機 & & & .0 \\
\hline 照明 & & & ㅇ. \\
\hline 空調 & . & & . \\
\hline 通信多重化 & & & . \\
\hline ヒトの移動 & t & & 0. \\
\hline モノの転用 & & & $0 \ldots$ \\
\hline ヒトの代行 & & & $\vdots \quad 0 \quad \vdots$ \\
\hline
\end{tabular}

2）本論分で参照するコールセンターでは、ガスの料金問い合わせ、開䦥栓依頼、器具故 障修理受付を担当している。主たる業務行為は以下のとおりである。料金の問い合 わせは、䳡客のデーターベースを情報端末で確認し、回答している。開閉栓依頼は 訪問係のスケジュールを情報端末で確認しながら顧客と訪問日時を調整し、情報端 末で訪問倸のスケジュールを予約している。器具修理受付は、メーカー名と機種番 号ならびに症状を確認し、修理係のスケジュールを情報端末で確恐しながら鹤客と 訪閭日時を調整し、情報端末て修理係のスケジュールを予約している。

業務を円滑に進めるために必要なファシリティには、鹤客の要望を把握し関俥部 門に業務を依頼するための通信手段、料金履歴や機器仕様や取り扱い方を参照し対 処を記録する情報機器、執務に利用する机・椅子・文房具、マニュアルやIT 画面 を見やすくする照明、通信機器や情叝機器を作動させるための電源ならびに空調、 電源・空調を運転するためのエネルギー・給排水設備、生活行為としての食事や排 泄に必要な空間と給排水設備などがある。

通信手段か確保されるなら、効率は低下するものの紙と鉆筆でも半日程度なら業 務遂行可能と想定している。

3）有馬高梘リニアメントに起因する地震の 30 年生起確率は、ほぼ0\%〜0.02\%と評価 されている ${ }^{15)}$

\section{参考文献}

1）朝日新聞 : 車販売際立つ失速 消費回復仲間はずれ、朝日新聞繀别版 2004.7 .28 朝刊、8面

2）朝日新聞：消費者軽視「命取り、朝日新聞縮刷版 2002.2 .23 朝刊、11 面

3）朝日新聞：半導体など縮小 経営計画発表 最終赤字 2330 億门、朝日新聞縮屌版 
2005.11.19朝刊、3面

4）内閣府防災担当: 事業釈続ガイドライン第一版 一わか国企業の減災と災害対応の 向上のために一、2005.8.1版、入手先 (http://www.bousai.go.jp/

MinkanTaShijyou/guideline01.pdf)、2006.11 入手

5）高橋一郎、中村政則 : 地震リスクマネジメント (SRM）手法による重要施設の震 災対策の定量謤価一新聞印刷工場の検討例一、日本建築学会大会学術講演集 (中国) \#40452、pp.941-942、1999.9

6）諏訪仁、野畑有秀、関松太郎：複数建物の地震りスク評価に関する檢討、日本建築 学会大会学術講演集 (関東) \#20019、pp.37-38、2001.9

7）水谷守、吉田伸一、今塚善勝、阿知波正道：広域に存在する施設群に対する地震リ スク評価（Part 1）、日本建築学会大会学術講演集（関東）＃20020、pp.39-44、 2001.9

8）平山恵子、浦川豪、佐十原聡、村上處直 : 鶴見区エリアにおける病院施設を中心と した災害医療のあり方に関する検討一地震災害対応面から見た地域医療ポテンシ ヤル評価に関する研究（その2）、日本建築学会大会学術講演集（東北）＃7187、 pp.373-374、2000.9

9）機械振興協会経済研究所：「国内生産拠点の分散化と集中化一新渴県中越地震か らの教訓一」、機械情報産業カレントレポートNo．9、2004.12 版、入手先 (http://www.eri.jspmi.or.jp/tyousa/current/current_9.pdf)、2006.11 入手

10）洪元和、村上公哉, 尾島俊雄 : 病院の非常時建築設備機能の重要度及び必要割 合の調查分析、日本建築学会計画系論文集、第 458 号、17-25、1994.4

11）洪元和、村上公哉、尾鳥俊雄 : 㕂舎の非常時建築設備の重要度及び必要割合の
調查分析、日本建築学会計画系論文集、第 468 号、37-45、1995.2

12）飯村龍、辻本誠：平常時との連続性を考虑した災害影㗽評価のための圾論、日 本建築学会大会学術講演集（関東）、＃7390、pp.779-780、1997.9

13） 飯村龍、河野守：平常時との連続性を考虑した災害影響と防災対策の評価 生活用水の防災対策の場合一、日本建築学会大会学術講演集（九州）、\#7422、 pp.843-844. 1998.9

14）後藤洋三他 : ディレクティビティ効果を考虑した内陸活断層による最大地動の 評価法、第 31 回地盤工学研究発表会 (北見) E-8、pp.1117-1118、地盤工学 会、 1996.

15）文部科学省研究開発局地震・防災研究課: 有馬一高睤断層帯の 30 年発生確率、 地震ハザードステーション・主要断層帯、2001.1.1 評価、入手先 (http://wwwj-shis.bosai.go.jp/)、2006.11 入手

16）柳父行二:コールセンターのブリーフィング（その1 基本的な考え方と対象 業務)、日本建築学会近畿支部研究報告集＃5073、pp.289-292、2004.6

17）柳父行二:コールセンターのプリーフィング(その2 インサイドアウト事例)、 日本建築学会近畿支部研究報告集、\#5089、pp.353-356、2005.6

18）柳父行二: コールセンターのブリーフィング（その3 基本計画の修正と補完 関係の活用事例)、日本建築学会近畿支部研究報告集、\#8024、pp.725-728、2006.6

19）柳父行二: コールセンターの設計要求条件整理、ワールドワークプレイス 2004 梗概集、pp.277-287、2004.3

（2006年12月10日原稿受理，2007年 7 月 18 日採用決定） 